\title{
Comparison of Properties of Hydroxyapatite Powders Synthesized by Chemical and Biomimetic Techniques
}

\author{
A.B. Hazar YoruÇ ${ }^{a}$, A. Karakaş ${ }^{b}$ A. KoyUn ${ }^{c}$ And T. Yildiz ${ }^{a}$ \\ ${ }^{a}$ Faculty of Chemical and Metallurgical Engineering, Department of Metallurgical and Materials Engineering \\ Ylldız Technical University, 34210 İstanbul, Turkey \\ ${ }^{b}$ Faculty of Arts and Science, Department of Chemistry, Yıldız Technical University, 34210 İstanbul, Turkey \\ ${ }^{c}$ Faculty of Mechanical Engineering, Department of Mechatronics Engineering, Ylldı Technical University \\ 34349 İstanbul, Turkey
}

\begin{abstract}
Hydroxyapatite $\left[\mathrm{HA} ; \mathrm{Ca}_{10}\left(\mathrm{PO}_{4}\right)_{6}(\mathrm{OH})_{2}\right]$ which composes inorganic phase of bones and teeth is one of the biomedical materials for artificial bone, reconstruction of broken or disordered bones, coating of metallic biomedical materials and dental surgery with its great biocompatibility. In this study, HA powders were synthesized from aqueous suspensions containing $\mathrm{H}_{3} \mathrm{PO}_{4}$ and $\mathrm{Ca}(\mathrm{OH})_{2}$ with $1.67 \mathrm{Ca} / \mathrm{P}$ ratios (chemical $\mathrm{HA}$, CHA) and second process is carried out in simulated body fluids consisting of $\left(\mathrm{NH}_{4}\right)_{2} \mathrm{HPO}_{4}$ and $\mathrm{Ca}\left(\mathrm{NO}_{3}\right)_{2} \cdot 4 \mathrm{H}_{2} \mathrm{O}$ as biomimetic hydroxyapatite (BHA). Moreover, properties of bovine HA (BoHA) and commercial HA (CoHA) were compared with properties of synthesized HA powders. Chemical structures of synthesized powders have been examined by the Fourier transform infrared technique and X-ray diffraction. The results showed that BHA powders have a pure HA content and no secondary phase, CHA also has monetite phase as secondary phase with HA in its structure. Particle size analysis was carried out with laser particle sizer and zeta-sizer, surface area of powders has been analyzed by the Brunauer-Emmett-Teller technique. Powder morphology is determined using scanning electron microscopy. As a result two different synthesis methods affected properties of HA powders.
\end{abstract}

PACS: $87.85 . J-$

\section{Introduction}

Calcium phosphates are primarily used as bone substitutes in biomedical industry due to their biocompatibility, low density, chemical stability and their compositional similarity to the mineral phase of bone [1]. Hydroxyapatite is a kind of calcium phosphate bioceramic materials and having a composition of $\mathrm{Ca}_{10}\left(\mathrm{PO}_{4}\right)_{6}(\mathrm{OH})_{2}$. $\mathrm{HA}$ is one of most widely investigated bioceramic materials and used bioceramics for bone and tooth substitution due to a structural similarity to the mineral part of calcified tissues [2-4].

During past few decades, considerable research efforts have been directed towards the synthesis of various bioceramics for biomedical applications. HA has close similarities with inorganic mineral component of hard tissues and possesses exceptional biocompatibility. HA ceramics do not exhibit any cytotoxic effects. Moreover HA can be directly bond to the bone. Unfortunately, due to low reliability, especially in wet environments, the HA cannot presently be used for heavy loadbearing applications, like artificial teeth or bones $[5,6]$. Various methods for the preparation of synthetic HA have been used, as hydrothermal method [7], hydrothermal-micro emulsion synthesis [8], chemical precipitation technique [6, 9], biomimetic preparation [10,11], sol-gel method [12], etc. The most widely used technique for synthesis of HA is chemical (or wet) precipitation technique. This technique uses raw materials at a reasonable cost [5]. It is possible to improve the properties of HA ceramic by controlling the process parameters such as particle size and shape, particle distribution and agglomeration. Nanocrystalline HA powders exhibit greater surface area. It can provide improved sinterability and enhanced densification to reduce sintering temperature. Moreover, nanosized HA is also expected to have better bioactivity than coarser crystals, nanophase ceramics clearly represent a unique and promising class of orthopedic/dental implant formulations with improved osseointegrative properties.

Recently, the use of precipitation and biomimetic techniques for synthesis of HA becomes an important research objective [6]. In this study, HA powders were synthesized from aqueous suspensions containing $\mathrm{H}_{3} \mathrm{PO}_{4}$ and $\mathrm{Ca}(\mathrm{OH})_{2}$ with $1.67 \mathrm{Ca} / \mathrm{P}$ ratios and second process is carried out in simulated body fluids (SBF) consisting of $\left(\mathrm{NH}_{4}\right)_{2} \mathrm{HPO}_{4}$ and $\mathrm{Ca}\left(\mathrm{NO}_{3}\right)_{2} \cdot 4 \mathrm{H}_{2} \mathrm{O}$ maintained at physiological $\mathrm{pH}$ and temperature (i.e., 7.4 and $37^{\circ} \mathrm{C}$, respectively), instead of pure water [10]. Moreover, properties of synthesized BoHA and CoHA samples were compared.

\section{Experimental parts}

$\mathrm{SBF}$ is known to be a metastable buffer solution and even a small, undesired variance in both of the preparation steps and the storage temperatures, may drastically affect the phase purity and high-temperature stability of the produced HA powders, as well as the kinetics of the precipitation processes [10]. SBF was prepared by dissolving reagent-grade mixtures of $\mathrm{NaCl}(6.547 \mathrm{~g} / \mathrm{L}, 99.5 \%), \mathrm{NaHCO}_{3}(2.268 \mathrm{~g} / \mathrm{L}, 99.5 \%)$, $\mathrm{KCl}(0.373 \mathrm{~g} / \mathrm{L}, 99 \%), \mathrm{Na}_{2} \mathrm{HPO}_{4} \cdot 2 \mathrm{H}_{2} \mathrm{O}(0.178,99.5 \%)$, 
$\mathrm{MgCl}_{2} \cdot 6 \mathrm{H}_{2} \mathrm{O}(0.305 \mathrm{~g} / \mathrm{L}, 98 \%), \mathrm{CaCl}_{2}(0,355 \mathrm{~g} / \mathrm{L}, 99 \%)$, $\mathrm{Na}_{2} \mathrm{SO}_{4}(0.355 \mathrm{~g} / \mathrm{L}, 99 \%),\left(\mathrm{CH}_{2} \mathrm{OH}\right)_{3} \mathrm{CNH}_{2}(6.057 \mathrm{~g} / \mathrm{L})$ in ultrapure water and buffering at $\mathrm{pH} 7.4$ with $1 \mathrm{M} \mathrm{HCl}$ at $37^{\circ} \mathrm{C}$

Calcium nitrate tetra hydrate $\left[\mathrm{CNT}, \mathrm{Ca}\left(\mathrm{NO}_{3}\right)_{2} \cdot 4 \mathrm{H}_{2} \mathrm{O}\right.$, $0.167 \mathrm{M}$ ] and diammonium hydrogen phosphate [DHP, $\left.\left(\mathrm{NH}_{4}\right)_{2} \cdot \mathrm{HPO}_{4}, 0.1561 \mathrm{M}\right]$ solutions were used for precipitation as the calcium and phosphate precursors. CNT and DHP were separately dissolved in SBF. DHP solution was dropped slowly into CNT solution with stirring. $\mathrm{NH}_{3}$ and SBF (1:2) solution was used to adjust $\mathrm{pH}$ values of the final suspension. For aging process, the solution was left for a day at $37^{\circ} \mathrm{C}$. After aging period, solution were removed from $\mathrm{SBF}$, gently rinsed with ultrapure water, and dried at $80^{\circ} \mathrm{C}$ for $8 \mathrm{~h}$. The powders were ground by hand using an agate mortar. CoHA with $1.67 \mathrm{Ca} / \mathrm{P}$ ratio was made by reacting calcium hydroxide $\left[\mathrm{Ca}(\mathrm{OH})_{2}\right]$ with orthophosphoric acid $\left(\mathrm{H}_{3} \mathrm{PO}_{4}\right)$ in distilled water. After precipitation, the solution was left for a day to mature at room temperature. Right after that maturation, the precipitate was filtered, washed and powders were dried at $110^{\circ} \mathrm{C}$ for a day. CHA was supplied by Sigma Aldrich.

Hydroxyapatite powders were characterized by X-ray diffraction (XRD) and the Fourier transform infrared technique (FTIR) (Perkin Elmer Spect 100) to determine the purity of different powders. Specific surface area was measured by the BrunauerEmmett-Teller (BET) method using Quadrosorb SI. Thermogravimetric-differential thermal analysis was performed on HA powders in air atmosphere. The sample microstructures were investigated by scanning electron microscopy (SEM). Particle size of different powders was determined by zeta-sizer and master-sizer (Malvern Nano-ZS and Mastersizer 2000).

\section{Results and discussion}

The FTIR spectra of HA powders are given in Fig. 1 and show the characteristic transmittance bands of hydroxyapatite. The band of BHA at $3210 \mathrm{~cm}^{-1}$ is due to an $\mathrm{OH}$ stretching vibration confirming the presence of hydroxyl ion in the apatite lattice. Adsorbed water also

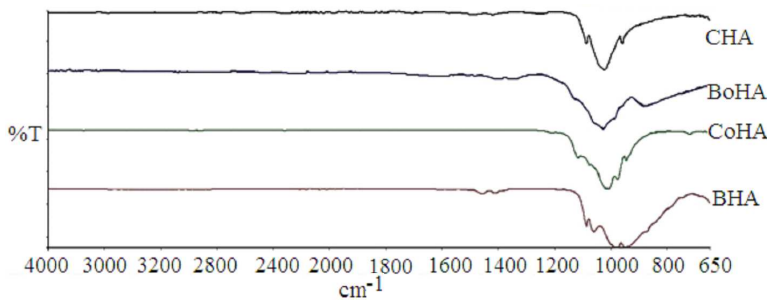

Fig. 1. FTIR spectra of HA powders.

displays a weak band at $1628 \mathrm{~cm}^{-1}$. The bands in the range $1084-953 \mathrm{~cm}^{-1}$ highlight the presence of $\mathrm{PO}_{4}^{3-}$ ions in the lattice. The $\mathrm{CO}_{3}^{2-}$ ion peaks were at $1407-1344$, $896-827 \mathrm{~cm}^{-1}$. Table shows specific surface area and particle size of the powders. Even as BHA and CHA were in nanoscale, CoHA was in micrometer scale. BET results support particle size analysis and as surface area increases, particle sizes of powders become smaller.

TABLE

Surface area and particle size results of powders.

\begin{tabular}{c|c|c}
\hline \hline Sample & $\begin{array}{c}\text { Surface area } \\
{\left[\mathrm{m}^{2} / \mathrm{g}\right]}\end{array}$ & $\begin{array}{c}\text { Particle size } \\
{[\mathrm{nm}]}\end{array}$ \\
\hline BHA & 56.95 & 105.8 \\
CHA & 33.22 & 198.9 \\
CoHA & 3.157 & 23170.0
\end{tabular}

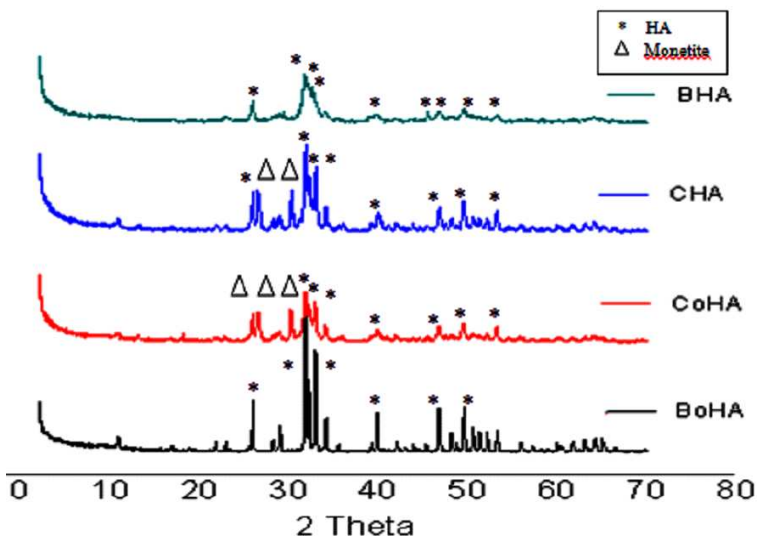

Fig. 2. XRD spectrum of HA samples.

In Fig. 2, XRD patterns of four samples are presented. The XRD results of BHA and BoHA samples indicated only the HA phase without any other phases, such as tricalcium phosphate (TCP). The diffraction patterns show exclusively sharp clear reflections especially for BoHA corresponding to hydroxyapatite, which confirms the phase purity and high crystallinity degree. For $\mathrm{CoHA}$ and $\mathrm{CHA}$, peaks indicate the hydroxyapatite into monetite phase $\left[\mathrm{CaPO}_{3}(\mathrm{OH})\right]$. It can be clearly seen that $\mathrm{CHA}$ and CoHA have the same patterns and the same secondary phases.

SEM was employed to detect the microstructural characteristics of the synthesized HA samples. The SEM images of HA powders are shown in Fig. 3. BoHA and CHA powders are spherical in shape and especially BoHA powders have some porous formations. BHA powder has very fine particles compared with other powders. On the other hand, CoHA powders had more irregular and rod-like structure. HA powders displayed a significant level of agglomeration. Considering that HA particles occur with the large number of crystals, agglomeration is expected to be encountered here.

\section{Conclusion}

The present study compared the properties of hydroxyapatite powders prepared by different methods. Chemically homogeneous, single-phase BHA powders with a 

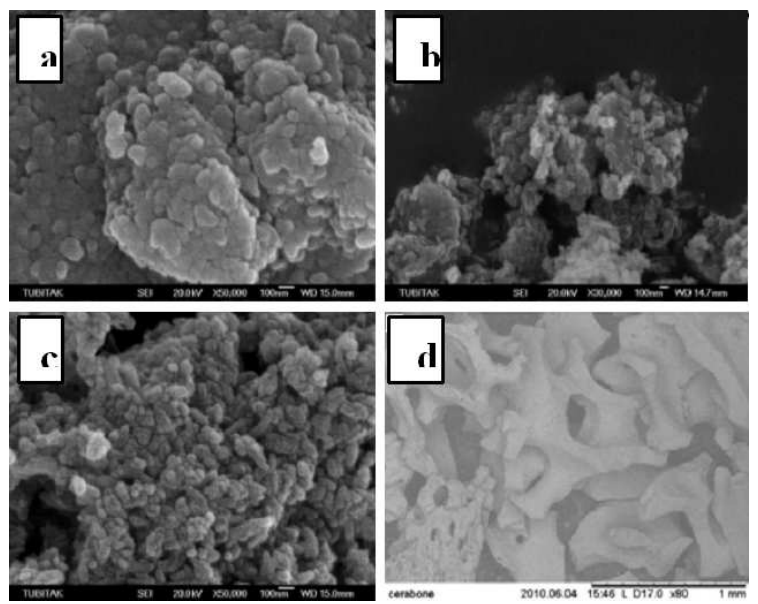

Fig. 3. SEM photographs of synthesized powders: (a) BHA $(50000 \times)$, (b) CHA (30000×), (c) CoHA (50000×), (d) BoHA (500x).

particle size about $100 \mathrm{~nm}$ were synthesized by precipitation technique via simulated body fluid at $\mathrm{pH} 7.4$ and $37^{\circ} \mathrm{C}$. XRD analysis of the samples showed that $\mathrm{CoHA}$ powder that has small amount of monetite as secondary phase synthesized by chemical precipitation meantime BHA was pure hydroxyapatite.

\section{Acknowledgments}

This work was supported by BAPK, Yildız Technical University and the authors would like to thank the sup- port of Yıldız Technical University Interdisciplinary Scientific and Technology Development Center.

\section{References}

[1] M.H. Fathia, A. Hanifi, V. Mortazavi, J. Mater. Process. Technol. 202, 536 (2008).

[2] S. Li, H. Izui, M. Okano, W. Zhang, T. Watanabe, in: Processing and Properties of Advanced Ceramics and Composites, Eds. N.P. Bansal, J.P. Singh, Materials Science and Technology Conference, Pennsylvania 2008, p. 93.

[3] M. Eriksson, Y. Liu, J. Hu, L. Gao, M. Nygren, Z. Shen, J. Eur. Ceram. Soc. 31, 1533 (2011).

[4] D. Grossin, S. Rollin-Martinet, C. Estournès, F. Rossignol, E. Champion, C. Combes, C. Rey, C. Geoffroy, C. Drouet, Acta Biomater. 6, 577 (2010).

[5] A.K. Nayak, Int. J. Chem. Tech. Res. 2, 903 (2010).

[6] I. Mobasherpour, M.S. Heshajin, A. Kazemzadeh, M. Zakeri, J. Alloys Comp. 430, 330 (2007).

[7] H.S. Liu, T.S. Chin, L.S. Lai, S.Y. Chiu, K.H. Chung, C.S. Chang, M.T. Lui, Ceram. Int. 23, 19 (1997).

[8] K. Lin, J. Chang, R. Cheng, M. Ruan, Mater. Lett. 61, 1683 (2007).

[9] H. Eslami, M. Solati-Hashjin, M. Tahriri, Iranian J. Pharmaceut. Sci. Spring 4, 127 (2008).

[10] A.C. Tas, Biomaterials 21, 1429 (2000).

[11] S. Benlioğlu, M.Sc. Thesis, Yıldız Technical University, 2011 (in Turkish).

[12] B. Cengiz, M.Sc. Thesis, Ankara Üniversity, 2007 (in Turkish). 